\title{
ANALISIS KUALITAS PRODUK, KUALITAS PELAYANAN, KONDISI EMOSIONAL, PERSEPSI HARGA DAN BIAYA TERHADAP KEPUASAN PESERTA JKN-KIS PEKERJA PENERIMA UPAH BADAN USAHA SWASTA DI BPJS KESEHATAN CABANG SAMPIT KALIMANTAN TENGAH
}

\author{
Adi Suci Guntoro \\ Sekolah Tinggi Ilmu Ekonomi Pancasetia Banjarmasin \\ Jl. Ahmad Yani Km. 5.5 Banjarmasin \\ adisuciguntoro@gmail.com
}

\begin{abstract}
Abstrak : Penelitian ini dilakukan untuk mengetahui pengaruh kualitas produk, kualitas pelayanan, kondisi emosional, persepsi harga dan biaya terhadap kepuasan pendaftaran peserta JKN-KIS pekerja penerima upah badan usaha swasta di BPJS Kesehatan Cabang Sampit Kalimantan Tengah. Penelitian ini menggunakan kuesioner pada 100 pekerja penerima upah badan usaha swasta. Hasil penelitian menunjukkan variabel kualitas produk, kualitas pelayanan dan persepsi harga berpengaruh signifikan terhadap kepuasan peserta JKN-KIS pekerja penerima upah badan usaha swasta. Sedangkan, untuk variabel kondisi emosional dan biaya tidak berpengaruh signifikan terhadap kepuasan peserta JKN-KIS pekerja penerima upah badan usaha swasta. Kemudian, variabel kualitas produk, kualitas pelayanan, kondisi emosional, persepsi harga dan biaya secara simultan berpengaruh kepuasan peserta JKN-KIS pekerja penerima upah badan usaha swasta dengan nilai $F$ hitung $(4,082)>\mathrm{F}$ tabel $(2,310)$. Berdasarkan hasil penelitian juga diketahui bahwa kualitas pelayanan adalah variabel yang paling berpengaruh terhadap kepuasan peserta JKN-KIS pekerja penerima upah badan usaha swasta dengan nilai Beta Coefficients 0,196.
\end{abstract}

Kata Kunci : JKN-KIS, kualitas produk, kualitas pelayanan, kondisi emosional, persepsi harga, biaya, kepuasan

\section{Latar belakang}

Undang-Undang Nomor 40 Tahun

2004 tentang Sistem Jaminan Sosial Nasional menyelenggarakan mekanisme Asuransi Kesehatan Sosial yang bersifat wajib (mandatory) dan bertujuannya agar semua penduduk Indonesia terlindungi dalam sistem asuransi, sehingga mereka dapat memenuhi kebutuhan dasar kesehatan masyarakat yang layak. Kesehatan adalah hak dasar setiap orang, dan semua warga negara berhak mendapatkan pelayanan kesehatan.

Keberhasilan Program JKN-KIS salah satunya dipengaruhi oleh kepuasan peserta JKN-KIS. Kepuasan adalah perasaan senang atau kecewa seseorang yang muncul setelah membandingkan antara persepsi atau kesannya terhadap kinerja atau hasil suatu produk dan harapanharapannya (Kotler, 2012). Dalam menentukan kepuasan konsumen ada lima faktor yang harus diperhatikan yaitu kualitas produk, kualitas pelayanan atau jasa, emosi, harga dan biaya (Lupyoadi, 2011).

Dalam penyelenggaran jaminan kesehatan setiap peserta JKN-KIS dapat menilai atau mengevaluasi kualitas dengan mengukur respon seseorang setelah menerima jasa karena dengan adanya penilaian akan jasa tersebut maka sarana pelayanan kesehatan tersebut diharapkan tetap dapat berdiri dan semakin berkembang (Edberg 2009).

$$
\text { Kepesertaan JKN-KIS telah }
$$

mencapai 224.149.019 jiwa per 31 Desember 2019 dari berbagai segmen kepesertaan atau lebih dari $85 \%$ penduduk Indonesia. Dari jumlah tersebut, hampir 36 juta peserta (beserta keluarga) merupakan pekerja yang didaftarkan oleh pemberi kerjanya yang terdiri dari peserta pekerja Badan Usaha baik dari BUMN, BUMD, dan Badan Usaha Swasta (beserta keluarga) (BPJS Kesehatan, 2020). 
Berdasarkan data BPJS Kesehatan tahun 2019 pertanggal 31 Desember 2019 di Indonesia capaian jumlah peserta program JKN-KIS sebesar 218.132.478 jiwa terdiri dari kepersertaan berdasarkan segmentasi PBI APBN sebesar 96.097.366 jiwa, PBI APBD sebesar 35.313.599 jiwa, PPU-PN sebesar 17.230.127 jiwa, PPU-BU sebesar 32.915.385 jiwa, PBPU-Pekerja mandiri sebesar 31.424.849 jiwa dan bukan pekerja sebesar 5.151.152 jiwa (BPJS Kesehatan, 2019).

Berdasarkan data Kantor BPJS Kesehatan Cabang Sampit tahun 2017 didapat data kepesertaan BPJS jenis pekerja penerima upah (PPU) sebanyak 279.078 orang meningkat pada tahun 2018 sebesar 303.973 orang serta pada pertanggal 31 Desember 2019 sebesar 355.605 orang.

Selain karena kuantitas kepesertaan JKN-KIS segmen PPU Badan Usaha Swasta yang semakin meningkat dari tahun ke tahun, segmen ini pula yang memberikan kontribusi besar dari sisi iuran dengan angka klaim rasio yang lebih minim dibandingkan segmen lainnya sehingga termasuk dalam good customer. Berbeda dengan kategori PBI yang pendaftarannya dilakukan oleh Pemerintah baik pusat maupun daerah ataupun segmen PBPUPekerja mandiri yang lebih memiliki kecenderungan moral hazard dalam melakukan pendaftaran di saat sakit, pengaruh kepuasan peserta lebih dominan berperan terhadap inisiasi pendaftaran segmen PPU Badan Usaha Swasta dibandingkan segmen lainnya.

Tujuan dari penelitian ini adalah untuk mengetahui pengaruh kualitas produk, kualitas pelayanan, kondisi emosional, persepsi harga dan biaya terhadap kepuasan peserta JKN-KIS pekerja penerima upah badan usaha swasta di BPJS Kesehatan Cabang Sampit Kalimantan Tengah

\section{Studi Literatur}

\subsection{Kualitas Produk}

\section{a. Pengertian}

Menurut Kotler \& Armstrong (2012) adalah kemampuan suatu produk untuk melakukan fungsi-fungsinya. Kemampuan itu meliputi daya tahan produk, kehandalan, ketelitian yang dihasilkan, kemudahan operasikan dan diperbaiki, dan atribut lain yang berharga pada produk secara keseluruhan.

\section{b. Dimensi Kualitas Produk}

Kualitas produk memiliki dimensi yang dapat digunakan untuk menganalisis karakteristik dari suatu produk. Menurut Tjiptono (2016) kualitas produk memiliki delapan dimensi sebagai berikut :

1. Performance (kinerja), merupakan karakteristik operasi pokok dari produk inti (core product) yang dibeli.

2. Features (fitur atau ciri-ciri tambahan), yaitu karaktersitik sekunder atau pelengkap.

3. Reliability (reliabilitas), yaitu kemungkinan kecil akan mengalami kerusakan atau gagal dipakai.

4. Confermance to Specifications (kesesuaian dengan spesifikasi), yaitu sejauh mana karakteristik desain dan operasi memenuhi standar-standar yang telah ditetapkan sebelumnya.

5. Durability (daya tahan), yaitu berkaitan dengan berapa lama produk tersebut dapat digunakan.

6. Serviceability, meliputi kecepatan, kompetensi, kenyamanan, kemudahan direparasi; serta penanganan keluhan secara memuaskan.

7. Esthetics (Estetika), yaitu daya tarik produk terhadap panca indera.

8. Perceived Quality (kualitas yang dipersepsikan), yaitu citra dan reputasi produk serta tanggung jawab perusahaan terhadapnya.

\subsection{Kualitas Pelayanan \\ a. Pengertian}

Menurut Tjiptono menyatakan bahwa kualitas pelayanan adalah tingkat keunggulan yang diharapkan dan pengendalian atas tingkat keunggulan tersebut untuk memenuhi keinginan pelanggan.

b. Dimensi kualitas layanan

Menurut Parasuraman dalam Algifari (2019) dimensi kualitas layanan yaitu :

1. Ketersediaan fasilitas fisik (tangible) untuk pelayanan 
2. Ketepatan petugas dalam memberikan pelayanan (reliability)

3. Kemauan dan kesiapan petugas dalam memberikan pelayanan (responsiveness)

4. Keterampilan dan pengetahuan petugas dalam memberikan pelayanan (competence)

5. Sikap (sopan, respek, perhatian, keramahan) petugas dalam memberikan pelayanan (courstesy)

6. Kejujuran dan dapat dipercaya terhadap petugas dalam memberikan pelayanan (credibility)

7. Keamanan (fisik, keuangan, kerahasiaan) yang harus diberikan oleh petugas pelayanan (security)

8. Kemudahan untuk dihubungi atau ditemui petugas dalam memberikan pelayanan (access)

9. Cara berkomunikasi yang dimiliki oleh petugas dalam memberikan pelayanan (communication)

10. Usaha petugas dalam memahami kebutuhan konsumen (understanding the customer)

\subsection{Kondisi Emosional}

\section{a. Pengertian}

Emosional didasarkan pada perasaan atau sikap seseorang dalam bereaksi pada suatu kondisi. Emosional adalah suatu perasaan dan pikiran yang khas, suatu keadaan biologis, psikologis dan serangkaian kecenderungan untuk bertindak (Goleman, 2012).

\section{b. Dimensi Emosi}

Menurut Goleman (2012) dimensi kecerdasan emosi antara lain :

1. Self awareness, artinya mengetahui keadaan dalam diri, hal-hal yang lebih disukai, dan intuisi. Kompentensi dalam dimensi pertama adalah mengenali emosi sendiri, mengetahui kekuatan dan keterbatasan diri, dan keyakinan akan kemampuan sendiri.

2. Self regulation, artinya mengelola keadaan dalam diri dan sumber daya diri sendiri. Kompetensi dimensi kedua ini adalah menahan emosi dan dorongan negatif, menjaga norma kejujuran dan integritas, bertanggung jawab atas kinerja pribadi, luwes terhadap perubahan, dan terbuka terhadap ide-ide serta informasi baru.

3. Motivation, artinya dorongan yang membimbing atau membantu peraihan sasaran atau tujuan. Kompetensi dimensi ketiga adalah dorongan untuk menjadi lebih baik, menyesuaikan dengan sasaran kelompok atau organisasi, kesiapan untuk memanfaatkan kesempatan, dan kegigihan dalam memperjuangkan kegagalan dan hambatan.

4. Empathy, yaitu kesadaran akan perasaan, kepentingan, dan keprihatinan orang. Dimensi ke-empat terdiri dari kompetensi understanding others, developing others, customer service, menciptakan kesempatan-kesempatan melalui pergaulan dengan berbagai macam orang, membaca hubungan antara keadaan emosi dan kekuatan hubungan suatu kelompok.

5. Social skills, artinya kemahiran dalam menggugah tanggapan yang dikehendaki oleh orang lain. Diantaranya adalah kemampuan persuasi, mendengar dengan terbuka dan memberi pesan yang jelas, kemampuan menyelesaikan pendapat, semangat leadership, kolaborasi dan kooperasi, serta team building.

\subsection{Persepsi Harga}

\section{a. Pengertian}

Menurut

Tjiptono

(2016)

menyebutkan bahwa harga merupakan satusatunya unsur bauran pemasaran yang mendatangkan pemasukan atau pendapatan bagi perusahaan. Sedangkan menurut Buchari Alma (2013), mengemukakan bahwa harga adalah nilai suatu barang yang dinyatakan dengan uang.

Berdasarkan beberapa definisi di atas maka dapat diketahui bahwa harga adalah nilai dari suatu produk dalam bentuk uang yang harus dikorbankan atau dikeluarkan oleh konsumen guna mendapatkan produk yang diinginkan, sedangkan bagi produsen atau pedagang harga dapat menghasilkan pendapatan atau sebagai pemasukan bagi produsen tersebut. 


\section{b. Dimensi Harga}

Menurut Kotler dan Armstrong (2012) menjelaskan ada empat ukuran yang dapat mencirikan harga, yaitu keterjangkauan harga, kesesuaian harga dengan kualitas produk, kesesuaian harga dengan manfaat dan daya saing.

1. Keterjangkaun Harga

Konsumen bisa menjangkau harga yang telah ditetapkan oleh perusahaan. Produk biasanya ada beberapa jenis dalam satu merek harganya juga berbeda dari yang termurah sampai termahal.

2. Kesesuaian harga dengan kualitas produk Harga sering dijadikan sebagai indikator kualitas bagi konsumen orang sering memilih harga yang lebih tinggi diantara dua barang karena mereka melihat adanya perbedaan kualitas. Apabila harga lebih tinggi orang cenderung beranggapan bahwa kualitasnya juga lebih baik.

3. Kesesuaian harga dengan manfaat

Konsumen memutuskan membeli suatu produk jika manfaat yang dirasakan lebih besar atau sama dengan yang telah dikeluarkan untuk mendapatkannya. Jika konsumen merasakan manfaat produk lebih kecil dari uang yang dikeluarkan maka konsumen akan beranggapan bahwa produk tersebut mahal dan konsumen akan berpikir dua kali untuk melakukan pembelian ulang.

4. Harga sesuai kemampuan atau daya saing harga

Konsumen sering membandingkan harga suatu produk dengan produk lainnya, dalam hal ini mahal murahnya suatu produk sangat dipertimbangkan oleh konsumen pada saat akan membeli produk tersebut.

\subsection{Biaya}

\section{a. Pengertian}

Menurut Kuswadi (2015), biaya adalah semua pengeluaran untuk mendapatkan barang atau jasa dari pihak ketiga, baik yang berkaitan dengan usaha pokok perusahaanmaupun tidak. Biaya diukur dalam unit moneter dan digunakan untuk menghitung harga pokok produk yang diproduksi perusahaan.

\section{b. Dimensi biaya}

Dimensi atau kategori biaya Baldric dkk (2014), dapat diklasifikasikan berdasarkan :

1. Ketertelusuran biaya

Berdasarkan ketertelusuran biaya ke produk, biaya dapat digolongkan menjadi dua, yaitu :

a) Biaya langsung (direct cost) adalah biaya yang dapat ditelusur sampai kepada produk secara langsung.

b) Biaya tidak langsung (indirect cost) adalah biaya yang tidak dapat secara langsung ditelusur ke produk.

2. Perilaku Biaya

Berdasarkan perilakunya, biaya dapat diklasifikasikan menjadi 3 bagian yaitu

a) Biaya variabel (variable cost) adalah biaya yang jumlah totalnya berubah sebanding dengan perubahan tingkat aktivitas.

b) Biaya tetap (fixed cost) adalah biaya yang jumlahnya tidak terpengaruh oleh tingkat aktivitas dalam kisaran tertentu.

c) Biaya campuran (mixed cost) adalah biaya yang memiliki karakteristik biaya variabel dan sekaligus biaya tetap.

3. Fungsi pokok perusahaan

Berdasarkan fungsi pokok perusahaan, biaya dapat diklasifikasikan :

a) Biaya produksi (production cost) adalah biaya untuk membuat bahan menjadi produk jadi.

b) Biaya pemasaran (marketing expense) meliputi berbagai biaya yang terjadi untuk memasarkan produk atau jasa.

c) Biaya administrasi dan umum (general and administrative expense) adalah biaya yang terjadi dalam rangka mengarahkan, menjalankan, dan mengendalikan perusahaan.

4. Elemen biaya produksi

Berdasarkan fungsi produksi, biaya dapat diklasifikasikan menjadi tiga, yaitu:

a) Biaya bahan baku (raw material cost) adalah nilai bahan baku yang digunakan dalam proses produksi untuk diubah menjadi produk jadi. 
b) Biaya tenaga kerja langsung (direct labor cost) adalah besarnya nilai gaji dan upah tenaga kerja yang terlibat langsung untuk mengerjakan produk.

c) Biaya overhead pabrik (manufacture overhead cost) adalah semua biaya produksi selain biaya bahan baku dan biaya tenaga kerja langsung.

\subsection{Kepuasan}

\section{a. Pengertian}

Kepuasan adalah perasaan senang atau kecewa seseorang yang muncul setelah membandingkan antara persepsi/kesan terhadap kinerja atau hasil suatu produk dan harapan- harapannya (Kotler, 2012). Sedangkan menurut Rangkuti (2010), kepuasan konsumen adalah respon atau reaksi terhadap ketidaksesuaian antara tingkat kepentingan sebelumnya dan kinerja aktual yang dirasakan setelah penggunaan atau pemakaian.

\section{b. Elemen kepuasan konsumen}

Menurut Wilkie (2014) menyatakan bahwa terdapat 5 elemen dalam kepuasan konsumen yaitu :

1. Harapan (expectations)

Harapan konsumen terhadap suatu barang atau jasa telah dibentuk sebelum konsumen membeli barang atau jasa tersebut. Pada saat proses pembelian dilakukan, konsumen berharap bahwa barang atau jasa yang mereka terima sesuai dengan harapan, keinginan dan keyakinan mereka. Barang atau jasa yang sesuai dengan harapan konsumen akan menyebabkan konsumen merasa puas.

2. Prestasi (performance)

Pengalaman konsumen terhadap kinerja aktual barang atau jasa ketika digunakan tanpa dipengaruhi oleh harapan mereka. Ketika kinerja aktual barang atau jasa berhasil maka konsumen akan merasa puas.

3. Perbandingan (comparison)

Hal ini dilakukan dengan membandingkan harapan kinerja barang atau jasa sebelum membeli dengan persepsi kinerja aktual barang atau jasa tersebut. Konsumen akan merasa puas ketika harapan sebelum pembelian sesuai atau melebihi perepsi mereka terhadap kinerja aktual produk.

4. Konfirmasi (confirmation/disconfirmation)
Harapan konsumen dipengaruhi oleh pengalaman mereka terhadap penggunaan merek dari barang atau jasa yang berbeda dari orang lain. Confirmation terjadi bila harapan sesuai dengan kinerja aktual produk. Sebaiknya disconfirmation terjadi ketika harapan lebih tinggi atau lebih rendah dari kinerja aktual produk. konsumen akan merasa puas ketika tejadi confirmation / discofirmation.

\section{c. Faktor-faktor mempengaruhi kepuasan}

yang

Dalam menentukan kepuasan konsumen ada lima faktor yang harus diperhatikan oleh perusahaan (Lupyoadi, 2011) antara lain :

1. Kualitas produk, yaitu pelanggan akan merasa puas bila hasil mereka menunjukkan bahwa produk yang mereka gunakan berkualitas.

2. Kualitas pelayanan atau jasa, yaitu pelanggan akan merasa puas bila mereka mendapatkan pelayanan yang baik atau sesuai dengan yang diharapkan.

3. Emosi, yaitu pelanggan akan merasa bangga dan mendapatkan keyakinan bahwa orang lain akan kagum terhadap dia bila menggunakan produk dengan merek tertentu yang cenderung mempunyai tingkat kepuasan yang lebih tinggi. Kepuasan yang diperoleh bukan karena kualitas dari produk tetapi sosial atau self esteem yang membuat pelanggan merasa puas terhadap merek tertentu.

4. Harga, yaitu produk yang mempunyai kualitas yang sama tetapi menetapkan harga yang relatif murah akan memberikan nilai yang lebih tinggi kepada pelanggan.

5. Biaya, yaitu pelanggan yang tidak perlu mengeluarkan biaya tambahan atau tidak perlu membuang waktu untuk mendapatkan suatu produk atau jasa cenderung puas terhadap produk atau jasa tersebut.

\section{d. Dimensi Kepuasan}

Menurut Kotler, dkk (2012), Dimensi kepuasan menggunakan lima dimensi, yaitu

1. Kehandalan (reliability) yaitu kemampuan perusahaan untuk memberikan pelayanan sesuai dengan yang dijanjikan 
secara akurat dan terpercaya. Indikator kehandalan (reliability) yakni :

a) Prosedur pelayanan yang handal

b) Ketepatan pemenuhan janji

2. Daya

Tanggap (responsiveness) yaitu suatu kebijakan untuk membantu dan memberikan pelayanan yang cepat (responsif) dan tepat kepada pelanggan, dan penyampaian informasi yang jelas, Indikatornya adalah :

a) Kemampuan perusahaan untuk cepat tanggap dalam menghadapi masalah yang timbul.

b) Kemampuan perusahaan cepat tanggap terhadap keluhan yang disampaikan pelanggan.

3. Jaminan (assurance) yaitu

pengetahuan, kesopan santunan, dan kemampuan para pegawai perusahaan untuk menumbuhkan rasa percaya para pelanggan kepada perusahaan. Indikator jaminan (assurance) adalah :

a) Bonus tambahan bagi karyawan

b) Kemampuan dan kesopanan karyawan

4. Empati (empathy) yaitu

memberikan perhatian yang tulus dan bersifat individual atau pribadi yang diberikan kepada para pelanggan dengan berupaya memahami keinginan konsumen. Atau syarat untuk peduli, memberi perhatian pribadi pada pelanggan. Indikator empati (empathy) adalah :

a) Perhatian Karyawan

b) Pelayanan pribadi yang diberikan kepada pelanggan

5. Bukti Fisik (tangibles) yaitu kemampuan suatu perusahaan dalam menunjukkan eksistensinya kepada pihak eksternal. Penampilan fisik, peralatan, serta penampilan seluruh personil dan media yang terlibat dalam penyediaan pelayanan. Indikator bukti fisik (tangibles) adalah :
a) Fasilitas fisik
b) Perlengkapan
c) Penampilan karyawan

\section{a. Pengertian}

Jaminan Kesehatan Nasional (JKN) yang dikembangkan di Indonesia merupakan bagian dari Sistem Jaminan Sosial Nasional (SJSN). Sistem Jaminan Sosial Nasional ini diselenggarakan melalui mekanisme Asuransi Kesehatan Sosial yang bersifat wajib (mandatory) berdasarkan UndangUndang No.40 Tahun 2004 tentang Sistem Jaminan Sosial Nasional. Tujuannya adalah agar semua penduduk Indonesia terlindungi dalam sistem asuransi, sehingga mereka dapat memenuhi kebutuhan dasar kesehatan masyarakat yang layak (Kemenkes-RI, 2014).

\section{b. Kepesertaan JKN}

Kepersertaan dalam Program Jaminan Kesehatan Nasional dijelaskan dalam Peraturan Presiden Republik Indonesia Nomer 82 tahun 2018 tentang Jaminan Kesehatan. Peserta jaminan kesehatan meliputi PBI Jaminan Kesehatan yaitu kepesertaan ditetapkan oleh menteri yang menyelenggarakan urusan pemerintahan di bidang sosial sedangkan Bukan PBI Jaminan Kesehatan yaitu PPU dan anggota keluarganya, PBPU dan anggota keluarganya; dan BP dan anggota keluarganya.

\section{Metode Penelitian}

Penelitian ini merupakan penelitian kuantitatif dengan metode observasional analitik serta menggunakan pedekatan cross sectional. Adapun yang menjadi populasi dalam penelitian ini adalah semua HRD/Personalia/PIC Badan Usaha swasta peserta JKN-KIS di wilayah kerja BPJS Kesehatan Kantor Cabang Sampit sebanyak 2.323 orang dengan Teknik pengambilan sampel menggunakan slovin sebanyak 100 responden. 
Tabel 1 Definisi Operasional

\begin{tabular}{|c|c|c|c|c|c|}
\hline No & V Variabel & $\begin{array}{c}\text { Definisi } \\
\text { Operasional }\end{array}$ & Alat Ukur & Skala & Kategori \\
\hline 1 & $\begin{array}{l}\text { Kualitas } \\
\text { produk }\end{array}$ & $\begin{array}{l}\text { Kemampuan } \\
\text { produk } \\
\text { melakukan fun } \\
\text { fungsinya meli } \\
\text { daya tahan pro } \\
\text { kehandalan, } \\
\text { ketelitian } \\
\text { dihasilkan, } \\
\text { kemudahan } \\
\text { operasikan } \\
\text { diperbaiki, } \\
\text { atribut lain } \\
\text { berharga } \\
\text { produk } \\
\text { keseluruhan }\end{array}$ & 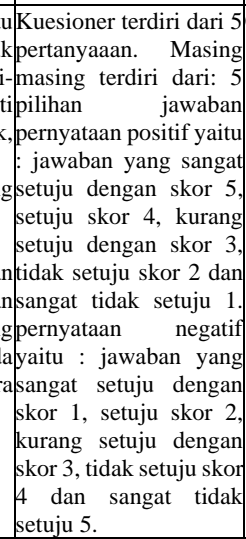 & \begin{tabular}{|l|l|}
5 & Ordinal \\
& \\
& \\
& \\
& \\
& \\
& \\
& \\
& \\
\end{tabular} & $\begin{array}{l}\text { Tidak baik } \\
8-24 \\
\text { Baik : } 25 \\
40\end{array}$ \\
\hline 2 & $\begin{array}{l}\text { Kualitas } \\
\text { pelayanan }\end{array}$ & $\begin{array}{lr}\text { Tingkat } & \text { keungg } \\
\text { untuk } & \text { meme } \\
\text { keinginan pelang }\end{array}$ & $\begin{array}{l}\text { nuesioner terdiri dari 5 } \\
\text { aipertanyaan. Masing } \\
\text { masing terdiri dari: 5 } \\
\text { pilihan jawaban } \\
\text { pernyataan positif yaitu } \\
: \text { jawaban yang sangat } \\
\text { setuju dengan skor 5, } \\
\text { setuju skor 4, kurang } \\
\text { setuju dengan skor 3, } \\
\text { tidak setuju skor 2 dan } \\
\text { sangat tidak setuju 1. } \\
\text { pernyataan negatif } \\
\text { yaitu : jawaban yang } \\
\text { sangat setuju dengan } \\
\text { skor 1, setuju skor 2, } \\
\text { kurang setuju dengan } \\
\text { skor 3, tidak setuju skor } \\
4 \text { dan sangat tidak } \\
\text { setuju 5. }\end{array}$ & \begin{tabular}{|l|l|}
5 & Ordinal \\
5 & \\
& \\
& \\
& \\
& \\
& \\
& \\
\end{tabular} & $\begin{array}{l}\text { Tidak baik } \\
10-30 \\
\text { Baik :31- } 50\end{array}$ \\
\hline 3 & $\begin{array}{l}\text { Kondisi } \\
\text { emosional }\end{array}$ & \multicolumn{2}{|c|}{ 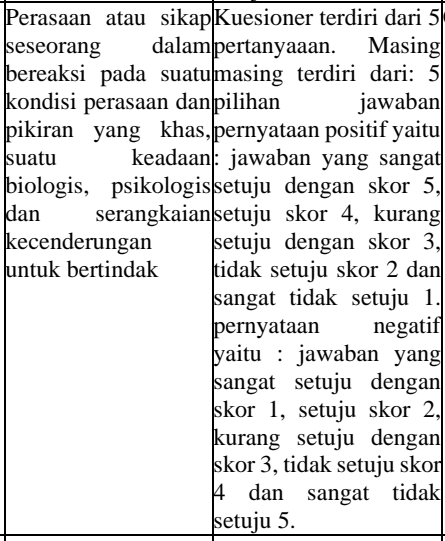 } & \begin{tabular}{|l} 
Sord \\
\\
\\
$\mathrm{g}$ \\
$\mathrm{n}$ \\
$\mathrm{n}$ \\
$\mathrm{n}$ \\
$\mathrm{f}$ \\
$\mathrm{g}$ \\
$\mathrm{n}$ \\
$\mathrm{n}$ \\
$\mathrm{n}$ \\
$\mathrm{n}$ \\
$\mathrm{k}$
\end{tabular} & $\begin{array}{l}\text { Tidak baik } \\
5-15 \\
\text { Baik : } 16 \\
25\end{array}$ \\
\hline 4 & $\begin{array}{l}\text { Persepsi } \\
\text { harga }\end{array}$ & \multicolumn{2}{|c|}{ 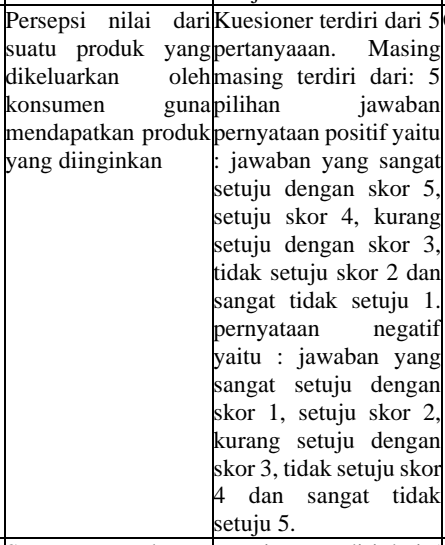 } & Ordinal- & $\begin{array}{l}\text { Tidak baik } \\
5-15 \\
\text { Baik : } 16 \\
25\end{array}$ \\
\hline 5 & Biaya & $\begin{array}{l}\text { Semua pengelu } \\
\text { untuk mendapa } \\
\text { barang atau jasa } \\
\text { pihak ketiga, } \\
\text { yang berka } \\
\text { dengan usaha po } \\
\text { perusahaan mau } \\
\text { tidak. }\end{array}$ & 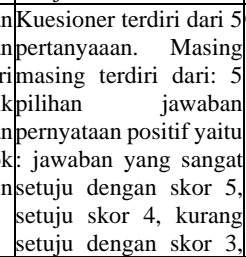 & Or & $\begin{array}{l}\text { Tidak baik } \\
4-12 \\
\text { Baik : } 13 \\
20\end{array}$ \\
\hline
\end{tabular}

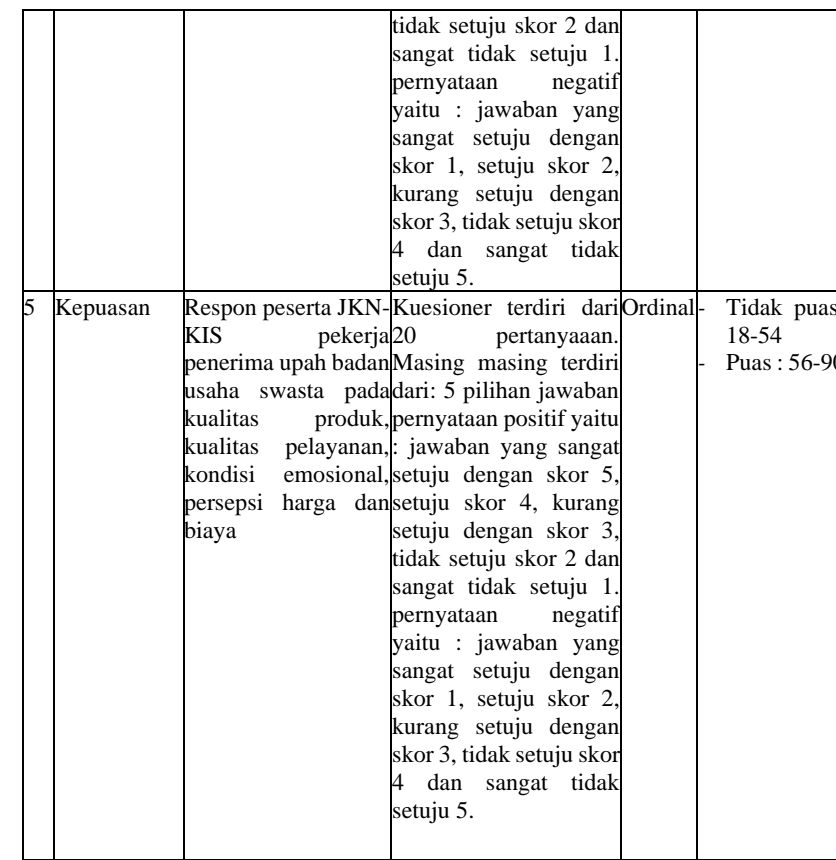

Teknik analisis data yang dipergunakan untuk mengetahui secara bersama-sama hubungan variabel independen terhadap variabel dependen menggunakan analisis regresi yang terdiri dari Uji Signifikansi (t), Uji Simultan (F), Dominan dan Uji Koefisien Determinasi (R2). Sebelum analisis data dilakukan, terlebih dahulu dilakukan uji instrument (Uji Validitas dan realibilitas) dan uji asumsi klasik (Uji Normalitas, Heteroskedastisitas, Multikolinearitas, Autokorelasi) sebagai persyaratan yang harus dipenuhi dalam kelompok variabel.

\section{Hasil penelitian dan Pembahasan 4.1 Hasil penelitian}

\section{a. Hasil Uji Instrument}

Berdasarkan pengujian dengan teknik person correlation diketahui setiap item pada kuesioner memiliki $r_{x y}>r_{\text {tabel }}$ yaitu sebesar 0,444 maka berdasarkan pengukuran tersebut diketahui bahwa kuesioner yang digunakan sah atau valid. Hasil pengukuran juga menunjukan hasil koefisien cronbach's alpha pada setiap variable menunjukan nilai lebih dari 0,600 sehingga dapat disimpulkan kuesioner menunjukkan konsistensi dalam mengukur gejala yang sama atau reliabel.

\section{b. Hasil Uji Asumsi Klasik}


Berdasarkan hasil Uji Kolmogorovsmirnov pada Kualitas Produk, Kualitas Pelayanan, Kondisi Emosional, Persepsi Harga, Biada dan Kepuasan didapat nilai $p$ $>0,05$ dengan demikian distribusi data normal atau data hasil transformasi mempunyai sebaran normal. Uji Heteroskedastisitas menunjukkan bawah terdapat penyebaran diatas dan dibawah nol pada sumbu Y, dimana hal tersebut menunjukkan bahwa tidak terjadi gejala heteroskedasitas pada data yang digunakan. Uji Multikolinieritas menunjukkan hasil output diatas diketahui untuk nilai VIF pada Kualitas Produk, Kualitas Pelayanan, Kondisi Emosional, Persepsi Harga, Biada dan Kepuasan didapat nilai tolerance $>0,1$ sedangkan untuk nilai VIF $<10$, maka mengacu pada dasar pengambilan keputusan dalam uji multikolinearitas dapat disimpulkan bahwa tidak terjadi gejala multikolinearitas atau dengan kata lain model regresi ini terbebas dari gejala multikolinearitas. Uji Autokorelasi nilai Durbin Watson $(\mathrm{DW})=1,804$ Sementara itu, nilai Durbin Watson tabel dengan data $\mathrm{n}=100$ didapat nilai DU (Durbin Upper $)=$ 1,780 dan DL (Durbin Lower) = 1,571 oleh karena nilai Durbin Watson hitung ( $\mathrm{dw}=$ 1,804) lebih besar dari pada nilai batas atas nilai Durbin Watson tabel $(\mathrm{dU}=1,780)$ maka tidak terdapat autokorelasi positif. kemudian oleh karena nilai Durbin Watson hitung $(4-1,804=2,196)$ lebih besar dari pada nilai batas atas nilai Durbin Watson tabel $(\mathrm{dU}=1,780)$ maka tidak terdapat autokorelasi negatif. Sehingga secara keseluruhan dapat disimpulkan tidak terdapat masalah autokorelasi.

\section{c. Analisis Regresi}

1. Uji Signifikansi (t)

Uji parsial digunakan untuk menguji pengaruh kualitas produk $\left(\mathrm{X}_{1}\right)$, kualitas pelayanan $\left(\mathrm{X}_{2}\right)$, kondisi emosional $\left(\mathrm{X}_{3}\right)$, persepsi harga $\left(\mathrm{X}_{4}\right)$, biaya $\left(\mathrm{X}_{5}\right)$ terhadap Kepuasan (Y) secara parsial. Uji parsial dalam penelitian ini dapat dilihat sebagai berikut :

\section{Tabel 2 Hasil Uji t}

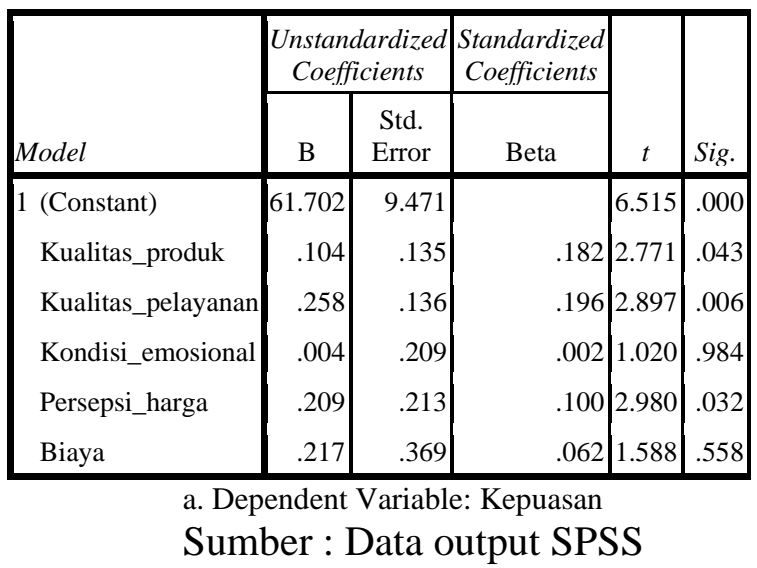

Berdasarkan hasil uji SPSS diatas, maka persamaan regresi yang mencerminkan variabel - variabel dalam penelitian ini adalah :

Keterangan :

$\mathrm{X}_{1} \quad$ : Kualitas produk

$\mathrm{X}_{2}$ : Kualitas pelayanan

$\mathrm{X}_{3} \quad$ : Kondisi emosional

$\mathrm{X}_{4} \quad$ : Persepsi harga

$\mathrm{X}_{5} \quad$ : Biaya

$\mathrm{Y} \quad$ : Kepuasan

a : Konstanta

$b_{1} b_{2}$ : Koefisien regresi

e : Error (faktor pengganggu)

\begin{tabular}{|c|c|}
\hline$Y=$ & $a+b_{1} X_{1}+b_{2} X_{2}+b_{3} X_{3}+b_{4} X_{4}+b_{5} X_{5}+$ et \\
\hline$Y=$ & $\begin{array}{c}61.702+(0,104) X_{1}+(0,258) X_{2}+(0,04) X_{3}+(0,209) X_{4}+(0,217) \\
X_{5}+e I\end{array}$ \\
\hline
\end{tabular}

Berdasarkan pengujian SPSS diatas diketahui pada kualitas produk didapat nilai t hitung sebesar $(2,771)$ $>\mathrm{t}$ tabel (1,985), maka dapat disimpulkan bahwa ada pengaruh kualitas produk dengan kepuasan.

Berdasarkan pengujian SPSS diatas diketahui pada kualitas pelayanan didapat nilai $\mathrm{t}$ hitung sebesar $(2,897)>\mathrm{t}$ tabel $(1,985)$, maka dapat disimpulkan bahwa ada pengaruh kualitas pelayanan dengan kepuasan.

Berdasarkan pengujian SPSS diatas diketahui pada kondisi emosional didapat nilai $\mathrm{t}$ hitung sebesar $(1.020)<\mathrm{t}$ tabel $(1,985)$, maka dapat disimpulkan bahwa tidak ada pengaruh kondisi emosional dengan kepuasan. 
Berdasarkan pengujian SPSS diatas diketahui pada persepsi harga didapat nilai $\mathrm{t}$ hitung sebesar $(2,980)>\mathrm{t}$ tabel $(1,985)$, maka dapat disimpulkan bahwa ada pengaruh persepsi harga dengan kepuasan.

Berdasarkan pengujian SPSS diatas diketahui pada biaya didapat nilai t hitung sebesar $(1,588)<\mathrm{t}$ tabel $(1,985)$, maka dapat disimpulkan bahwa tidak ada pengaruh biaya dengan kepuasan.

\section{Uji Simultan (F)}

Uji signifikansi simultan (uji F) yang digunakan dalam model mempunyai pengaruh bersamasama terhadap variabel dependennya. Analisis menggunakan uji $\mathrm{F}$ menunjukkan bahwa semua variabel independen secara simultan merupakan penyelasan yang signifikan terhadap variabel dependen.

\section{Tabel 3 Hasil Uji F}

\section{ANOVA $^{b}$}

\begin{tabular}{l|r|r|r|r|r|}
\hline Model & \multicolumn{1}{|c|}{$\begin{array}{c}\text { Sum of } \\
\text { Squares }\end{array}$} & Df & $\begin{array}{c}\text { Mean } \\
\text { Square }\end{array}$ & F & Sig. \\
\hline 1 Regression & 457.434 & 5 & 91.487 & 4.082 & $.003^{\mathrm{a}}$ \\
Residual & 7945.076 & 94 & 84.522 & & \\
Total & 8402.510 & 99 & & & \\
\hline
\end{tabular}
a. Kualitas_pelayanan, (Constant), Biaya, Kondisi_emosional,
Persepsi_harga, Kualitas_produk
b. Dependent Variable: Kepuasan

Sumber : Data output SPSS

Dari hasil uji Anova atau uji $\mathrm{F}$ diatas menunjukkan nilai $\mathrm{F}$ hitung $(4,082)>\mathrm{F}$ tabel (2,31) maka dapat disimpulkan bahwa hipotesis diterima atau dengan kata lain kualitas produk $\left(\mathrm{X}_{1}\right)$, kualitas pelayanan $\left(\mathrm{X}_{2}\right)$, kondisi emosional $\left(\mathrm{X}_{3}\right)$, persepsi harga $\left(\mathrm{X}_{4}\right)$, biaya $\left(\mathrm{X}_{5}\right)$ secara simultan berpengaruh terhadap kepuasan (Y).

3. Variabel Paling Berpengaruh (Dominan)

Berdasarkan hasil uji penelitian menunjukan nilai Beta (Beta Coefficients) yang terbesar ada pada Variabel Kualitas Pelayanan $\left(\mathrm{X}_{2}\right)$ sebesar 0,196> nilai Beta (Beta Coefficients) variabel lain yang berpengaruh yaitu kualitas produk $\left(\mathrm{X}_{1}\right)$ sebesar 0,182 dan persepsi harga $\left(\mathrm{X}_{4}\right)$ sebesar 0,100 sehingga dapat disimpulkan bahwa faktor Kualitas
Pelayanan adalah yang paling berpengaruh terhadap kepuasan (Y).

\section{Uji Koefisien Determinasi $\left(\mathrm{R}^{2}\right)$}

Nilai koefisien determinasi yang ditujukan dengan nilai Adjusterd $R$ Square dari model regresi digunakan untuk mengetahui seberapa besar kemampuan variabel bebas dalam menerangkan variabel terikat.

\section{Tabel 4 Hasil Uji Koefisien}

Determinasi $\left(\mathrm{R}^{2}\right)$

\begin{tabular}{l|r|r|r|r|}
\hline Model & $\mathrm{R}$ & $\begin{array}{c}\mathrm{R} \\
\text { Square }\end{array}$ & $\begin{array}{c}\text { Adjusted R } \\
\text { Square }\end{array}$ & $\begin{array}{c}\text { Std. Error of the } \\
\text { Estimate }\end{array}$ \\
\hline 1 & $.933^{\mathrm{a}}$ & .870 & .865 & .762 \\
\hline a. & Predictors: (Constant), Biaya, Kondisi_emosional, \\
& Kualitas_pelayanan, \\
Persepsi_harga, Kualitas_produk \\
b. Dependent Variable: Kepuasan \\
Sumber : Data output SPSS
\end{tabular}

Dari tabel diatas diketahui bahwa nila R squared sebesar 0,870 hal ini berarti $87 \%$ variabel kualitas produk, kualitas pelayanan, kondisi emosional, persepsi harga, biaya secara bersama-sama berpengaruh terhadap variabel kepuasan. Sedangkan sisanya $(100 \%-87 \%=13 \%)$ dipengaruhi oleh variabel lain di luar dari variabel yang diteliti.

\subsection{Pembahasan}

a. Pengaruh kualitas produk terhadap kepuasan peserta JKN-KIS pekerja penerima upah badan usaha swasta

Berdasarkan pengujian SPSS pada tabel 2 diketahui pada kualitas produk didapat nilai $\mathrm{t}$ hitung sebesar $(2,771)>\mathrm{t}$ tabel (1,985), maka dapat disimpulkan bahwa ada pengaruh kualitas produk dengan kepuasan.

Kualitas merupakan perpaduan antara sifat dan karakteristik yang menentukan sejauh mana keluaran dapat memenuhi persyaratan kebutuhan pelanggan atau menilai sampai seberapa jauh sifat dan karakteristik itu memenuhi kebutuhannya (Tjiptono, 2012).

Kualitas produk dapat mempengaruhi kepuasan konsumen. Kepuasan tergantung oleh kualitas produk perusahaan, karena jika semakin tinggi tingkat kualitas poduk 
maka semakin tinggi tingkat kepuasan konsumen yang dihasilkan (Kotler dan Keller, 2012).

Hasil penelitian ini didukung oleh penelitian Wijaya dan Fajriana (2018) mengatakan bahwa kualitas produk tercermin dari kualitas produk yang diberikan berdasarkan pandangan dari pelanggan, ketika perusahaan mampu memberikan pelayanan yang sesuai dari harapan konsumen maka konsumen akan puas terhadap produksi tersebut.

b. Pengaruh kualitas pelayanan terhadap kepuasan peserta JKN-KIS pekerja penerima upah badan usaha swasta

Berdasarkan pengujian SPSS pada tabel 2 diketahui pada kualitas pelayanan didapat nilai $\mathrm{t}$ hitung sebesar $(2,897)>\mathrm{t}$ tabel (1,985), maka dapat disimpulkan bahwa ada pengaruh kualitas pelayanan dengan kepuasan.

Kualitas pelayanan (service quality) dapat diketahui dengan cara membandingkan persepsi konsumen atas pelayanan yang diperoleh dengan pelayanan yang diharapkan. Jika pelayanan yang diterima melampaui harapan konsumen, maka kualitas pelayanan dipersepsikan sangat baik dan berkualitas. Sebaliknya jika pelayanan yang diterima kurang baik daripada yang diharapkan, maka kualitas pelayanan dipersepsikan tidak baik (Tjiptono, Fandy, 2011).

Penelitian oleh Cassany (2017) bahwa persepsi kualitas pelayanan tang diberikan berpengaruh positif terhadap kepuasan termasuk kepuasan peserta Program JKNKIS dan hal ini menunjukkan bahwa semakin baik persepsi kualitas pelayanan maka akan semakin tinggi tingkat kepuasan peserta. Persepsi kualitas merupakan persepsi dari peserta maka persepsi kualitas tidak dapat ditentukan secara objektif. Persepsi peserta akan melibatkan apa yang penting bagi peserta karena setiap peserta memiliki kepentingan (yang diukur secara relatif) yang berbeda-beda terhadap suatu produk atau jasa.

Hasil penelitian ini didukung oleh Pantouvakis dan Bouranta (2015) mengatakan bahwa kepuasan pelanggan dan kualitas pelayanan terbukti secara kualitatif dan empiris merupakan konstruk yang multi-dimensi dimana komponen kualitas bersama dengan kenyamanan dan biaya mempengaruhi kepuasan keseluruhan pelanggan.

c. Pengaruh kondisi emosional terhadap kepuasan peserta JKN-KIS pekerja penerima upah badan usaha swasta

Berdasarkan pengujian SPSS pada tabel 2 diketahui pada kondisi emosional didapat nilai $\mathrm{t}$ hitung sebesar $(1.020)<\mathrm{t}$ tabel $(1,985)$, maka dapat disimpulkan bahwa tidak ada pengaruh kondisi emosional dengan kepuasan.

Kondisi emosi adalah situasi, persyaratan atau keadaan perasaan yang ada di dalam diri seseorang dalam bereaksi terhadap suatu kondisi. Bila kualitas jauh di bawah harapan, maka mereka akan mengalami ketidakpuasan emosional (emotional dissatisfaction). Bila kinerja melebihi harapan, maka mereka akan merasakan kepuasan emosional (emotional satisfaction). Bila kinerja dianggap sama dengan harapan, konsumen mengalami konfirmasi ekspektasi (expectancy confirmation) (Mowen dan Minor, 2011).

Hasil penelitian ini berbeda dengan penelitian Istiqoh (2017) mengatakan bahwa variabel emosional memiliki pengaruh positif terhadap kepuasan pelanggan. Hal ini memberikan makna bahwa semakin emosional seseorang tidak terkontrol maka semakin tidak puas terhadap pelayanan yang diberikan.

Salah satu yang menjadi penyebab variabel kondisi emosional tidak memiliki pengaruh yang signifikan adalah karena responden yang merupakan HRD, Personalia atau PIC dari Badan Usaha peserta JKN-KIS memiliki profesionilitas yang mumpuni dimana pekerjaan mereka lakukan dengan integritas tanpa melibatkan emosi secara pribadi. Sehingga baik dalam kondisi apapun emosinionalnya maka tidak akan mempengaruhi segala sesuatu yang berkaitan dengan pekerjaan yang sedang mereka lakukan. Hal inilah yang membuat perbedaan hasil pengaruh yang signifikan khususnya apabila responden seorang 
professional jika dibandingkan dengan responden dari kalangan non professional.

Pengaruh persepsi harga terhadap

kepuasan peserta JKN-KIS pekerja

penerima upah badan usaha swasta

Berdasarkan pengujian SPSS pada tabel 2 diketahui pada persepsi harga didapat nilai $\mathrm{t}$ hitung sebesar $(2,980)>\mathrm{t}$ tabel (1,985), maka dapat disimpulkan bahwa ada pengaruh persepsi harga dengan kepuasan.

Harga merupakan aspek yang sangat penting dalam sebuah instansi. Harga yang sudah layak dan masuk akal tercipta kepuasan pasien. Persepsi harga berkaitan dengan bagaimana informasi harga dipahami seluruhnya oleh konsumen dan memberikan makna yang dalam bagi mereka. Pada saat konsumen melakukan evaluasi terhadap harga dari suatu produk ini sangat dipengaruhi oleh perilaku dari konsumen itu sendiri (Peter dan Olson, 2012).

Penelitian ini didukung oleh penelitian Fatmawati (2017) Persepsi harga berpengaruh positif terhadap proses keputusan pembelian. Semakin menarik persepsi harga yang ditawarkan, maka akan meningkatkan proses keputusan pembelian (Fatmawati, 2017).

d. Pengaruh biaya terhadap kepuasan peserta JKN-KIS pekerja penerima upah badan usaha swasta

Berdasarkan pengujian SPSS pada tabel 2 diketahui pada biaya didapat nilai $\mathrm{t}$ hitung sebesar $(1,588)<\mathrm{t}$ tabel $(1,985)$, maka dapat disimpulkan bahwa tidak ada pengaruh biaya dengan kepuasan.

Biaya merupakan pengorbanan atau pengeluaran yang dilakukan oleh seseorang yang bertujuan untuk memperoleh manfaat lebih dari aktivitas yang dilakukan tersebut (Raharja putra, 2009).

Penelitian ini berbeda dengan penelitian Wijaya (2018) bahwa tarif iuran (biaya) berpengaruh positif dan signifikan terhadap tingkat kepuasan konsumen baik secara parsial maupun simultan.

Salah satu yang menjadi penyebab variabel biaya tidak memiliki pengaruh yang signifikan adalah karena responden yang merupakan HRD, Personalia atau PIC dari Badan Usaha peserta JKN-KIS dalam memperoleh pelayanan pendaftaran yang diterima tidak membutuhkan pengorbanan dalam biaya, hal ini disebabkan segala aktifitas operasionalnya baik yang mengakses pendaftaran secara online maupun pendaftaran manual ke lokasi kantor BPJS Kesehatan telah ditanggung ataupun dibiayai oleh perusahaan tempat responden bekerja. Hal inilah yang meminimalisir berkaitannya antara biaya yang sebenarnya tidak ditanggung langsung oleh responden dengan kepuasan pendaftaran yang timbul.

e. Pengaruh kualitas produk, kualitas pelayanan, kondisi emosional, persepsi harga dan biaya terhadap kepuasan peserta JKN-KIS pekerja penerima upah badan usaha swasta

Dari hasil uji Anova atau uji F diatas menunjukkan nilai $\mathrm{F}$ hitung $(4,082)>\mathrm{F}$ tabel $(2,31)$ maka dapat disimpulkan bahwa hipotesis diterima atau dengan kata lain kualitas produk $\left(\mathrm{X}_{1}\right)$, kualitas pelayanan $\left(\mathrm{X}_{2}\right)$, kondisi emosional $\left(\mathrm{X}_{3}\right)$, persepsi harga $\left(\mathrm{X}_{4}\right)$, biaya $\left(\mathrm{X}_{5}\right)$ secara simultan berpengaruh terhadap kepuasan (Y).

Kepuasan adalah perasaan senang atau kecewa seseorang yang muncul setelah membandingkan antara persepsi atau kesan terhadap kinerja atau hasil suatu produk dan harapan-harapannya (Kotler, 2012). Dalam menentukan kepuasan konsumen ada lima faktor yang harus diperhatikan oleh perusahaan antara lain kualitas produk, kualitas pelayanan atau jasa, emosi, harga dan biaya (Lupyoadi, 2011).

\section{Kesimpulan}

Berdasarkan hasil penelitian pada 100 responden mengenai kualitas produk, kualitas pelayanan, kondisi emosional, persepsi harga dan biaya terhadap kepuasan peserta JKN-KIS pekerja penerima upah badan usaha swasta didapat hasil sebagai berikut :

1. Kualitas produk berpengaruh terhadap kepuasan peserta JKN-KIS 
pekerja penerima upah badan usaha swasta.

2. Kualitas pelayanan berpengaruh terhadap kepuasan peserta JKN-KIS pekerja penerima upah badan usaha swasta.

3. Kondisi emosional tidak berpengaruh terhadap kepuasan peserta JKN-KIS pekerja penerima upah badan usaha swasta.

4. Persepsi harga berpengaruh terhadap kepuasan peserta JKN-KIS pekerja penerima upah badan usaha swasta.

5. Biaya tidak berpengaruh terhadap kepuasan peserta JKN-KIS pekerja penerima upah badan usaha swasta.

6. Kualitas produk, kualitas pelayanan, kondisi emosional, persepsi harga dan biaya secara simultan berpengaruh kepuasan peserta JKN-KIS pekerja penerima upah badan usaha swasta.

\section{DAFTAR PUSTAKA}

Algifari. 2019. Mengukur kualitas Pelayanan dengan mengukur kepuasan, metode importance performance analysis (IPA) dan Model Rano. Yogyakarta : BPEP.

Arikunto, S. 2010. Prosedur Penelitian Suatu Pendekatan Proses Edisi Revisi. Jakarta : Rineka Cipta.

Baldric, Bambang Suripto, Dodi Hapsori. dkk. 2014. Akuntansi Biaya. Edisi 2. Jakarta: Salemba Empat

BPJS Kesehatan Indonesia, 2019. Jumlah peserta BPJS Kesehatan PBI dan Non $P B I$. Jakarta : BPJS Kesehatan.

BPJS Kesehatan, 2017. Sejarah Perjalanan Jaminan Sosial di Indonesia. (https://bpjskesehatan.go.id/bpjs/pages/detail/201 3/4) (Diakses 1 Nopember 2019)

Cassany. 2017. Pengaruh Persepsi Kualitas Pelayanan Terhadap Kepuasaan Peserta JKN-KIS pada BPJS Kesehatan Cabang Banda Aceh IMEN (Akuntansi dan Manajemen) STIES Vol. 8 No 1 Juni 2017

Defa Septia. 2017. Kepuasan terhadap kualitas pelayanan BPJS kesehatan (Studi kasus di Rumah Sakit Abdul Moeloek Provinsi Lampung). Skripsi. Fakultas Ilmu Sosial Dan Politik
Universitas
Lampung
Bandar
Lampung

Edberg, Mark. 2009. Buku Ajar Kesehatan Masyarakat: Teori Sosial \& Perilaku. Jakarta : Buku Kedokteran EGC

Fatmawati. 2017. Kualitas Produk, Citra Merek Dan Persepsi Harga Terhadap Proses Keputusan Pembelian Konsumen Sepeda Motor Matic "Honda". Jurnal Manajemen Teori dan Terapan Tahun 10. No. 1, April 2017

Giese, J. L. dkk, 2000, Defining Customer Satisfaction, Academy of Science Review

Goleman, Daniel. 2012. Working With Emotional Intelligence (terjemahan). Jakarta : PT. Gramedia Pustaka Utama

Istiqo. 2017. Pengaruh Kualitas Pelayanan, Harga, Dan Faktor Emosional terhadap Kepuasan Pelanggan Pada Hotel The Sun Sidoarjo . Jurnal Bisnis Indonesia Vol. 8 No. 1 April 2017

Kemenkes. 201). Panduan Praktis Administrasi Klaim Fasilitas Kesehatan BPJS Kesehatan, Kemenkes-RI, Jakarta

Kotler dan Armstrong. 2012. Prinsipprinsip Pemasaran. Jakarta: Erlangga.

Kotler, Philip dan Kevin Lane Keller. 2008. Manajemen Pemasaran. Jilid 1. Jakarta

Kuswadi. 2015. Meningkatkan Laba dengan Pendekatan Akutansi Keuangan dan Akutansi Biaya. Jakarta : PT Elex Media Komputindo

Lupiyoadi, Rambat dan A. Hamdani. 2011. Manajemen Pemasaran Jasa. Edisi Dua. Jakarta: Salemba Empat.

Mowen, J.C, and Michael Minor. 2011. Perilaku Konsumen. Alih Bahasa: Lina Salim. Jakarta: Erlangga

Nggao. 2018. Indonesia Polemik Kebijakan Layanan BPJS Kesehatan. https:// mediaindonesia.com/read/detail/1760 17-polemik-kebijakan-layanan-bpjskesehatan (Diakses 20 Januari 2020)

Notoatmodjo, S. 2014. Metodologi Penelitian Kesehatan. Jakarta : Rineka Cipta 
Novita Resha Vianti. 2016. Analisis Kepuasan Pasien BPJS (Badan Penyelenggara Jaminan Sosial) Terhadap Pelayanan Kesehatan di Instalasi Rawat Inap (IRI) Bangsal Dahlia Rsud Ungaran. Skripsi. Jurusan Ilmu Kesehatan Masyarakafakultas Ilmu Keolahragaan Universitas Negeri Semarang

Pantouvakis, A. \& Bouranta, N. 2015. Quality and Price - Impact on Patient Satisfaction. International Journal of Health Care Quality Assurance; Bradford 27(8): 684-696.

Paul Peter \& jerry c. Olson. 2012. Consumer Behavior Perilaku Konsumen. Jakarta: .Penerbit Erlangga

Peraturan Badan Jaminan Penyelengaraan Kesehatan Nomer 1 tahun 2014 tentang Jaminan Penyelenggaraan Jaminan Kesehatan

Peraturan Badan Penyelenggara Jaminan Sosial Kesehatan Nomor 1 Tahun 2014 Tentang Penyelenggaraan Jaminan Kesehatan

Peraturan Menteri Pendayagunaan Aparatur Negara Dan Reformasi Birokrasi no 16 tahun 2014 tentang Pedoman Survey Kepuasaan Masyarakat Terhadap Penyelenggaraan Pelayanan Publik

Peraturan Presiden Republik Indonesia Nomer 82 tahun 2018 tentang Jaminan Kesehatan.

Raharja Putra. 2009. Manajemen Keuangan dan Akutansi Untuk Eksekutif Perusahaan, PT. Raja Grafindo Persada, Jakarta.

Rangkuti, Freddy. 2010, Measuring Customer Satisfaction. Gramedia Pustaka Utama, Jakarta.

Tjiptono dan Gregorius chandra. 2016. Service, Quality \& satisfaction. Yogyakarta. Andi.

Tjiptono, Fandy. 2011. Strategi Pemasaran. Edisi Pertama. Andi Ofset.Yogyakarta

Undang-Undang No.40 Tahun 2004 tentang Sistem Jaminan Sosial Nasional.
Wijaya. 2018. Tingkat kepuasaan pasien JKN-KIS BPJS Kesehatan di Kota Palembang. EKSIS Volume 13 Nomer 2 Oktober 2018

Wilkie, W.L 2014. Consumer Behavior. ed., John Wiley \& Sons. New York 